\title{
Fate of Insulin-Like Growth Factors I and II Administered Orogastrically to Suckling Rats
}

\author{
ANTHONY F. PHILIPPS, RADHAKRISHNA RAO, GARY G. ANDERSON, \\ DAVID M. MCCRACKEN, MATS LAKE, AND OTAKAR KOLDOVSKY \\ Department of Pediatrics [A.F.P, G.G.A., O.K.], Steele Memorial Children's Research Center, \\ Departments of Pharmacology [R.R] and Physiology [D.M.M., O.K.], University of Arizona College of \\ Medicine, Tucson, Arizona, and Kabi Pharmacia[M.L.], Stockholm, Sweden
}

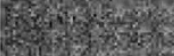

Milk-borne insulin-like growth factors I and II (IGF-I and -II) may be of importance in the differentiation of the gastrointestinal tract of the suckling. To test this hypothesis, 10- to 11-d-old suckling rats were given via an orogastric tube ${ }^{125}$ I-IGF-I $(n=6)$ or ${ }^{125}$ I-IGF-II $(n=6)$ in rat milk and killed 30 min later. The results of this study demonstrated that approximately $40 \%$ of the radioactivity administered was detected in the gastrointestinal tract for both ${ }^{125}$ I-IGF-I and ${ }^{125}$ I-IGF-II experiments. Gel chromatography of acid extracts of homogenates of gastrointestinal tissues and luminal contents demonstrated that a significant fraction of recovered radioactivity eluted in a position identical to "native" IGF. These findings were confirmed by subjecting similarly treated samples to high performance liquid chromatography. In addition, radioactive material recovered from $M_{\mathrm{r}} 7,500$ fractions bound specifically to crude membrane IGF-I and -II
\end{abstract}

receptor preparations, further suggesting the preservation of biologic activity of the recovered peptides. Although skin homogenates contained large peptide fragments of ${ }^{125}$ I-IGF-I, no "intact" IGF was found in the blood or other tissues. These findings suggest that milk-borne IGFs are stable in the neonatal gastrointestinal tract and remain biologically active for as long as 30 min postingestion. (Pediatr Res 37: 586-592, 1995)

\section{Abbreviations}

IGF, insulin-like growth factor

IGFBPs, IGF binding proteins

$\mathbf{R P}$, reversed phase

HPLC, high performance liquid chromatography

TCA, trichloroacetic acid
IGFs are peptides that bear significant homology to insulin and are produced by a variety of tissues in the developing mammal (1-3). IGF-I and -II have been observed to be potent mitogens and to have insulin-like effects on cellular metabolic processes such as glucose and amino acid uptake. Because these hormones and their receptors are ubiquitous during development, it has been suggested that IGFs may play a significant role in control of growth during the perinatal period, which is a time of rapid somatic and organ growth and differentiation (1-3). Recent studies using transgenic mice that either over or under express IGF transcripts have confirmed this supposition $(4,5)$. Recently, significant quantities of IGFs have been documented in the milk of several species, including the human (6-8). In the gastrointestinal tissues of the newborn

Received August 1, 1994; accepted January 10, 1995.

Correspondence and reprint requests: Anthony F. Philipps, M.D., Department of Pediatrics, Steele Memorial Children's Research Center, University of Arizona College of Medicine, Tucson, AZ 85724.

Supported by the National Institute of Health Grants DK26067 and HD26013, the Arizona Disease Control Commission No. 82-3018, and by the Virginia and Vernon Furrow Foundation.

Portions of this work were presented at the annual meeting of the American Gastroenterological Association in San Francisco, California, May 1992, and the European Society for Pediatric Research Meeting in Uppsala, Sweden, June 1992. rat and pig there are disparities between the relatively large rates of synthesis of IGF receptors, as measured by receptorspecific mRNA levels, and the lesser rates of synthesis of endogenous IGF $(9,10)$. Because of the known ease of absorption of other peptide hormones (11), and of lower digestion of proteins by the gastrointestinal tract of the newborn (12), the fate of orogastrically administered radiolabeled IGFs was determined, using the suckling rat as a model of premature newborn gastrointestinal function.

\section{METHODS}

Chemicals. Recombinant human IGF-I and -II were obtained from Kabi Pharmacia, Biosciences Laboratories, Stockholm, Sweden. Sephadex G-50 and BSA were purchased from Sigma Chemical Co., St. Louis, MO. ${ }^{125}$ Iodine, used for iodination of peptides, was purchased from Amersham Corp., Arlington Heights, IL. Iodination of IGF-I used the chloramine T method (13), and IGF-II was iodinated using a peroxidase method (14). Appropriate concentrations of each hormone preparation were then made in $50 \mathrm{mM}$ Tris- $\mathrm{HCl}, 0.2 \% \mathrm{BSA}$ for dilution in rat milk. The specific activities of ${ }^{125} \mathrm{I}-\mathrm{IGF}-\mathrm{I}$ and ${ }^{125} \mathrm{I}-\mathrm{IGF}-\mathrm{II}$ were $200-400 \mathrm{mCi} / \mathrm{mg}$ and $150-500 \mathrm{mCi} / \mathrm{mg}$, 
respectively. Both iodinated peptides were isolated using Sephadex G-25 gel chromatography and tested for specific activity using radioreceptor assays specific for type $\mathrm{I}$ and II receptors (see below). Rat milk of appropriate postnatal age was obtained from lactating mothers. Pups were removed $4 \mathrm{~h}$ before milk collection, and the mothers were then lightly anesthetized using Innovar-Vet (Pitman-Moore, Washington Crossing, NJ) $(10-40 \mu \mathrm{L} / \mathrm{rat})$. Each dam was given $1.0 \mathrm{U}$ oxytocin intraperitoneally and milked only once. Within 20 min of oxytocin injection, between 1.0 and $2.0 \mathrm{~mL}$ of milk was manually expressed into polystyrene test tubes and stored at $-40^{\circ} \mathrm{C}$ for further use.

Animals and Experimental Design. Six suckling rats each were used for both the IGF-I and -II feeding experiments. The animals used were male rats between 10 and $11 \mathrm{~d}$ postnatal age, weighing $20-25 \mathrm{~g}$ each. Litters were culled to 10 per litter routinely on $\mathrm{d} 2$. Rat pups were removed from their dams $4 \mathrm{~h}$ before administration of IGF and fasted after placement in a Plexiglas cage that was positioned so that one-half was situated over a heating pad at $33^{\circ} \mathrm{C}$. Before administration of IGF, urination was stimulated by gentle stimulation of the anogenital region. Rats were then given $200 \mu \mathrm{L}$ each of a 1:1 mixture of ${ }^{125}$ I-IGF-I or -II in whole rat milk using a $3.5 \mathrm{Fr}(1.2-\mathrm{mm}$ inside diameter) catheter (Sherwood Medical, St. Louis, MO) that was placed by mouth to a depth of approximately $4 \mathrm{~cm}$. The rat milk-IGF mixture was incubated for $30 \mathrm{~min}$ at $37^{\circ} \mathrm{C}$ before administration. The radioactivity dose administered to each animal was estimated by sampling an aliquot before feeding and was approximately $10 \times 10^{6} \mathrm{cpm}$ per animal (or 7-10 ng IGF, based on specific activities of ${ }^{125}$ I-IGF-I or -II). This represents approximately $15 \%$ of the daily estimated milk-borne IGF-I intake/day, or $2 \%$ of IGF-II intake/day of suckling rats at $10 \mathrm{~d}$ postnatal age (15).

After $30 \mathrm{~min}$, animals were decapitated while under light ether anesthesia. Trunk blood was then collected and allowed to clot for $30 \mathrm{~min}$ at $21^{\circ} \mathrm{C}$. Radioactivity of each blood sample was measured using a gamma counter (AutoGamma, Beckman Instruments, Palo Alto, CA), and radioactivity of whole blood total volume was calculated assuming a blood volume of $7 \%$ of body weight. Serum was separated by centrifugation at 3000 $\mathrm{rpm}$ for $15 \mathrm{~min}$, and samples stored at $70^{\circ} \mathrm{C}$ for later analysis.

Within 5-10 $\mathrm{min}$ after decapitation, the brain, liver, lungs, heart, thymus, spleen, kidneys, skin, stomach, and small intestine was removed from each animal. Care was taken to use clean instruments to prevent cross contamination of radioactivity. Each organ was immediately frozen in liquid nitrogen and radioactivity per organ assessed. For the stomach and intestine, the following modifications were made: 1 ) the stomach was dissected from the intestine at the pylorus, and the esophagus removed; 2) the stomach was incised longitudinally along the lesser curvature and opened; 3 ) the stomach luminal contents were gently scraped off, the mucosa flushed with 2.5 $\mathrm{mL}$ of ice-cold saline, and both content and saline wash combined as "stomach luminal content;" 4) the ice-cold saline solution was injected into the proximal small intestine and the resultant intestinal content and saline wash combined as "intestinal luminal content"; and 5) the combined contents and flushings from stomach and intestine, as well as stomach and intestine wall, were then frozen and counted (as above). It was noted that approximately $50 \%$ of the animals had urine visible within the bladder. Urine in volumes of $0.1-0.7 \mathrm{~mL}$ was aspirated by syringe from these pups and counted in individual tubes.

Acid Extraction and Chromatography. Because of the presence of IGFBPs, acid extraction of tissue homogenates and subsequent chromatography was necessary to identify ${ }^{125} \mathrm{I}-$ IGFs in tissues of fed animals. Organ homogenates were prepared in $5 \mathrm{~mL}$ of $0.1 \mathrm{M}$ acetic acid for $60 \mathrm{~s}$ each using a Polytron tissue homogenizer (Brinkman Instruments, Westbury, NY). In the case of luminal flushings, $0.2 \mathrm{M}$ acetic acid was used to bring the final homogenate concentration to $0.1 \mathrm{M}$. Each sample was then centrifuged at $5000 \mathrm{rpm}$ for $10 \mathrm{~min}$, and the supernatant was stored for later analysis. In the preliminary studies, ${ }^{125}$ I-IGF-I was added to similarly prepared rat liver homogenates. Supernatants removed contained $85-90 \%$ of the added radioactivity. Homogenate supernatants were stored at $-70^{\circ} \mathrm{C}$ and later thawed for chromatography. Selected specimens (four to six specimens from each gastrointestinal tissue and luminal flushings, pooled sera, and one to two homogenates from all other tissue specimens) were studied. A 3-mL aliquot of each specimen was counted, placed over a $1 \times$ 75-cm Sephadex G-50 column (Pharmacia Biotech Inc., Piscataway, NJ), and equilibrated against $0.1 \mathrm{M}$ acetic acid at a flow rate of $2.0 \mathrm{~mL} / \mathrm{h}(1.5-\mathrm{mL}$ fractions). Columns were calibrated using ${ }^{125}$ I-IGF-I, and the column volumes were defined using cobalt chloride and blue dextran (Sigma Chemical Co.). Chromatograph fractions were then removed and counted in a $\gamma$ counter. Radioactive peaks noted between 40 and $60 \%$ (fractions 45-55) of the column volume were lyophilized for later assessment of receptor-binding activity.

Radioactivity of tissue homogenates, blood and urine was also assessed for TCA precipitability. Equal volumes of sample and $20 \%$ TCA were added to polyethylene tubes and incubated for $30 \mathrm{~min}$ at $21-23^{\circ} \mathrm{C}$. Samples were centrifuged at $3000 \mathrm{rpm}$ for $15 \mathrm{~min}$ at $4^{\circ} \mathrm{C}$. Precipitates were washed with $10 \%$ TCA and centrifuged again for $15 \mathrm{~min}$. The remaining precipitates were examined for radioactivity and the amount remaining as a percent of the initial counts/min was calculated.

$\boldsymbol{R P}$-HPLC. Fractions from Sephadex chromatography representing peaks at approximately $M_{\mathrm{r}} 7,500$ were lyophilized and reconstituted in $500 \mu \mathrm{L}$ of $50 \mathrm{mM}$ Tris- $\mathrm{HCl}, 0.1 \%$ BSA. Specimens from the stomach and intestinal wall homogenates, as well as those from intestinal luminal contents, were injected into the HPLC column for analysis. A linear gradient of $5-60 \%$ acetonitrile against $0.1 \%$ trifluoroacetic acid, monitored at a flow rate of $1 \mathrm{~mL} / \mathrm{min}$ for $30 \mathrm{~min}$ (column temperature, $40^{\circ} \mathrm{C}$ ), was used to elute the samples from a VYDAC 18 column (The Separations Groups, Hesperia, CA) $(5 \mu \mathrm{m} ; 25 \mathrm{~cm}$ $\times 4 \mathrm{~mm}$ ), as described previously (16). Elution of ${ }^{125}$ I radioactivity was continuously monitored by a radioactivity flow detector (Radiomatic model A250, Flow One $\beta$, Tampa, FL) and recorded on a strip chart recorder. Radiolabeled IGF-I and -II were used as controls.

Receptor-Binding Studies. Human placental membranes (IGF-I studies) and rat liver membranes (IGF-II studies) were prepared, as previously described $(17,18)$. Human placental 
membranes were used to assess IGF-I binding to type I IGF receptors. Because of the known preponderance of type II IGF receptors in this tissue (18), rat liver membranes were used to assess IGF-II binding. Membranes (400 $\mu \mathrm{g}$ protein/tube) were incubated overnight at $4{ }^{\circ} \mathrm{C}$ with ${ }^{125} \mathrm{I}$-IGF, with or without an excess of unlabeled IGF-I $(20 \mathrm{ng} / \mathrm{mL})$ or $-\mathrm{II}(200 \mathrm{ng} / \mathrm{mL})$, in 50 $\mathrm{mM}$ Tris- $\mathrm{HCl}, 0.1 \%$ BSA, $\mathrm{pH} 7.4$. These concentrations were based on previous observations (our unpublished studies) documenting maximal suppression of labeled IGF binding to each membrane. Lyophilized "peaks" from six previously identified Sephadex G-50 chromatography samples were reconstituted in $50 \mathrm{mM}$ Tris- $\mathrm{HCl}$ and $0.1 \%$ BSA and incubated with or without excess unlabeled stock IGF. After incubation, specimens were centrifuged at $6500 \mathrm{rpm}$ for $30 \mathrm{~min}$ at $4^{\circ} \mathrm{C}$. The precipitates were washed with $0.75 \mathrm{~mL}$ Tris and recentrifuged. All precipitates were then counted and percent of binding (counts/min remaining/initial counts/min added) calculated to examine differences in the percentage of receptor-binding activity between labeled IGFs and organ homogenate "peaks.",

Statistical Analysis. All data are represented as mean \pm SEM. Differences between IGF-I and -II studies and in receptor-binding studies were assessed using unpaired and paired $t$ tests. Correlation of TCA precipitation studies with chromatography used linear regression analyses by the least squares method.

\section{RESULTS}

Recovery of Radioactivity. Suckling rats tolerated the administration of the radiolabeled IGF-milk mixture well ( $n=6$ for ${ }^{125}$ I-IGF-I and $n=6$ for ${ }^{125}$ I-IGF-II, respectively). Figure 1 depicts the recovery of radioactivity from selected organs and blood of IGF-treated rats $30 \mathrm{~min}$ after administration. The highest activities were observed in stomach luminal contents of animals treated with either ${ }^{125}$ I-IGF-I or -II. Overall, gastrointestinal tract tissues, including radioactivity present in stomach

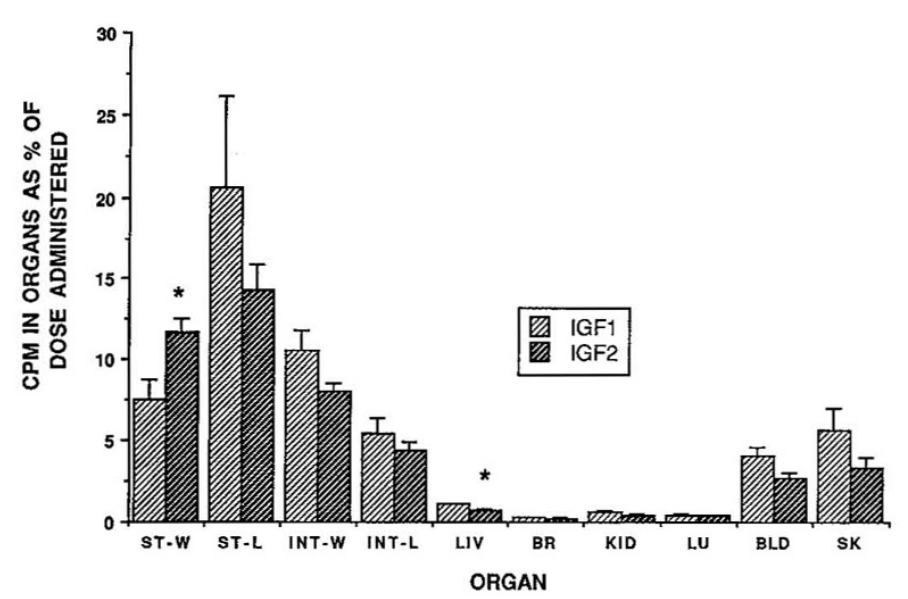

Figure 1. Distribution of radioactivity to selected organs and blood in animals fed ${ }^{125}$ I-IGF-I or -II 30 min previously. Results have been calculated as percent counts/min recovered of dose administered. $S T-L$, stomach lumen; $S T-W$, stomach wall; INT-L, intestinal lumen; INT-W, intestinal wall; $L I V$, liver; $B R$, brain; $K I D$, kidneys; $L U$, lungs; $B L D$; whole blood; and $S K$, skin. ${ }^{125} \mathrm{I}-\mathrm{IGF}-\mathrm{I}$ in light hatched bars, ${ }^{125} \mathrm{I}$-IGF-II in dark hatched bars. Data are presented as mean $\pm \mathrm{SEM},{ }^{*}=p<0.05$ between IGF-I- and -II-fed rats; $n$ $=6$ each group. wall and lumen and small intestinal wall and lumen, contained $42.3 \pm 5.0$ and $38.4 \pm 2.2 \%$ of the doses of ${ }^{125}$ I-IGF-I and -II administered, respectively. These results were not statistically different from each other. Within these tissues the only significant differences between values of animals fed ${ }^{125} \mathrm{I}$-IGF-I or -II were in the stomach wall $(11.7 \pm 0.9 \%$ versus $7.5 \pm 1.2 \%$, $p<0.05$, respectively). IGF-I and -II were retained in the stomach (wall + lumen) at a similar level (26-27\%). For both the IGF-I and -II studies, radioactivity present in stomach wall and luminal contents represented approximately $65 \%$ of the total gastrointestinal tract radioactivity overall. In other tissues, blood and skin radioactivity represented $4-7 \%$ of counts administered, with other individual organs having $<2 \%$ of the dose administered per organ. Of these, only liver radioactivities were found to be statistically different between IGF-I and -II fed animals $(1.1 \pm 0.1 \%$ versus $0.7 \pm 0.1 \%, p<0.05$, respectively). Urine radioactivity (not depicted) was $<0.05 \%$ of the administered dose in all animals from which urine could be obtained. Total radioactivity recovered per animal in the organs studied was between 45 and $65 \%$ of the doses administered for both the IGF-I and -II experiments.

Gel Chromatography Studies. Extracts of selected organ homogenates were subjected to acid gel chromatography and the resulting fractions assessed for radioactivity. In general, four to six homogenates from gastrointestinal tract tissues and luminal flushings were examined. Only two to three homogenates from other organs were examined. Figure 2 shows a typical chromatograph of stomach wall homogenate from an ${ }^{125}$ I-IGF-I-fed animal superimposed upon a chromatograph from a $5-\mu \mathrm{L}$ sample of ${ }^{125} \mathrm{I}-\mathrm{IGF}-\mathrm{I}$ milk mixture used for the feeding experiments. The patterns are similar with peak activity observed between 40 and $60 \%$ of the column volume (approximate $M_{\mathrm{r}}$ of $7,500=$ "7.5 K" peak). Similar elution profiles were noted when ${ }^{125}$ I-IGF-II was mixed with milk and subjected to chromatography. Small early peaks at fraction 30

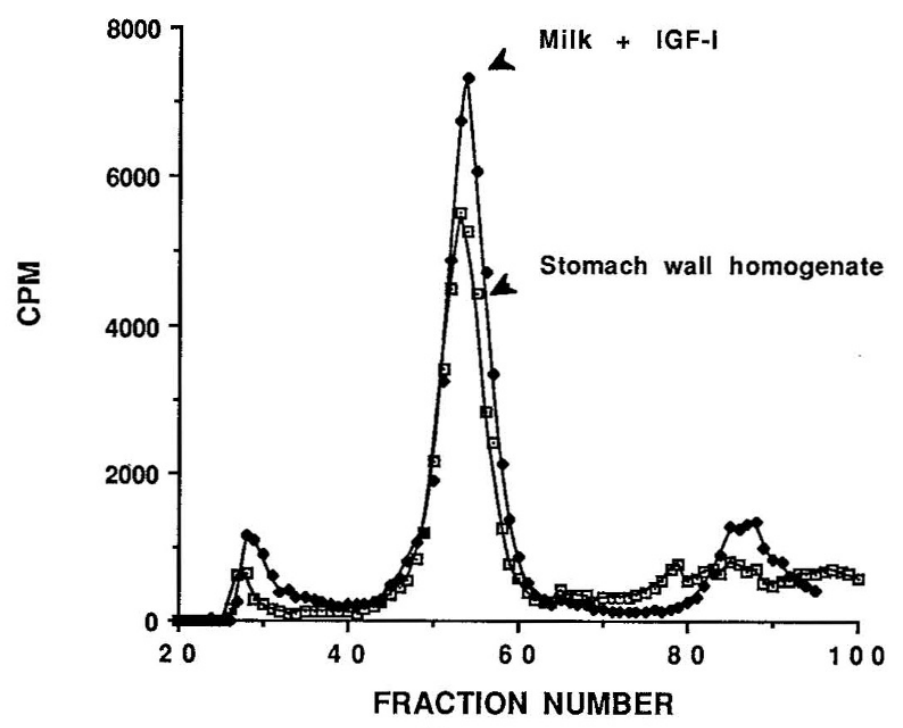

Figure 2. Chromatograph of milk ${ }^{125}$ I-IGF-I mixture $(5 \mu \mathrm{L})$ superimposed upon acid extract of stomach wall homogenates from ${ }^{125}$ I-IGF-I-fed animals. Sephadex G-50, 0.1 M acetic acid, $\mathrm{V}_{\mathrm{o}}=$ fractions 25-32, using blue dextran. Depending upon column used, ${ }^{125}$ I-IGF eluted between 40 and $60 \%$ of column volume (between fractions 45 and 55). 
are artifactual and are also apparent in some chromatographs in Figures 3 and 4 . These most likely represent iodine or small peptide fragments bound to albumin and other large molecular weight proteins. Figure $3 A-D$ shows representative chromatographs from gastrointestinal tract tissues of ${ }^{125}$ I-IGF-I fed animals. In stomach wall, stomach lumen, and intestinal lumen, significant peaks of radioactivity can be seen, eluting in a position identical with native IGF-I. However, in both intestinal lumen and wall, peaks $\mathrm{P}_{1}$ and $\mathrm{P}_{2}$ of radioactivity, probably representing ${ }^{125} \mathrm{I}$ and ${ }^{125} \mathrm{I}$-peptide fragments, are also apparent. Similar findings were noted in chromatographs from gastrointestinal tissues of animals fed ${ }^{125}$ I-IGF-II (Fig. $4 A-D$ ).

The percentages of radioactivity present in the peaks designated as $7.5 \mathrm{~K}$ versus the total radioactivity per chromatograph were then calculated for both IGF-I and -II studies. Figure 5 shows that for each tissue or luminal content examined, significantly more radioactivity was present in the $7.5 \mathrm{~K}$ peaks for animals fed ${ }^{125}$ I-IGF-I than for animals fed ${ }^{125}$ I-IGF-II. Stomach wall and luminal content homogenates from animals fed ${ }^{125}$ I-IGF-I had the highest percentage of activity in the $7.5 \mathrm{~K}$ peaks of any group $(69.5 \pm 7.4 \%$ and $62.9 \pm 6.9 \%$, respectively). Intestinal wall homogenates from animals fed ${ }^{125} \mathrm{I}$ IGF-II were the only ones devoid of activity at the $7.5 \mathrm{~K}$ position.

Chromatographs from serum of IGF fed animals showed radioactive peaks consistent only with ${ }^{125} \mathrm{I}$ or ${ }^{125} \mathrm{I}$-related small peptide fragments (data not shown). This was also true for all other samples tested, except skin. Skin homogenates from ${ }^{125}$ I-IGF-I fed (but not ${ }^{125}$ I-IGF-II fed) animals had a peak of radioactivity near, but not identical with, native IGF-I.

TCA precipitation of homogenate aliquots was also performed as an adjunct to the chromatography studies. The

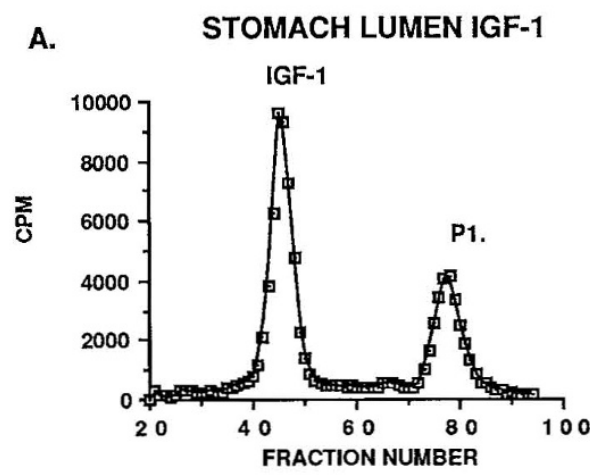

B. STOMACH WALL IGF-1

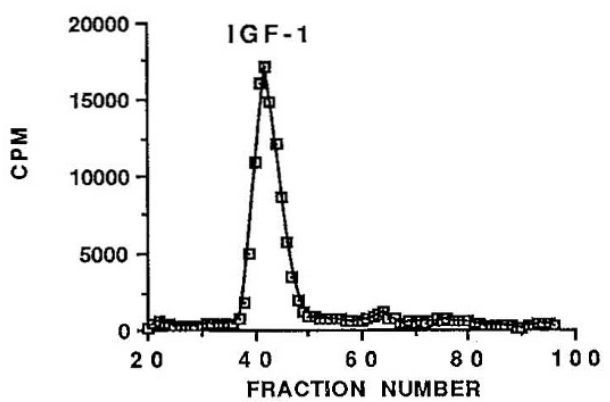

percentage of TCA precipitation per homogenate was compared with the percentage of activity found in the $7.5 \mathrm{~K}$ peak per sample for all gastrointestinal tract and liver samples. Linear regression analyses revealed significant correlations between TCA-precipitable radioactivity and $7.5 \mathrm{~K}$ peak radioactivity for both ${ }^{125}$ I-IGF-I and -II studies $(r=0.79, p<0.01$; and $r=0.85, p<0.01$, respectively).

$\boldsymbol{R P}$-HPLC Studies. Figure $6 A$ (IGF-I) and $B$ (IGF-II) depict the distribution of radioactivity from material taken from the $M_{\mathrm{r}}$ 7,500 peaks identified from homogenates of stomach wall and intestinal lumen and wall using simple gel chromatography. As shown by arrows in Figure $6 A$ and $B$, the peak identified comigrates with that of the control native radiolabeled IGF. Intestinal wall homogenates from IGF-II-fed animals had no demonstrable activity at $M_{\mathrm{r}} 7,500$ either by gel chromatography or HPLC.

Receptor-Binding Studies. Lyophilized fractions from the $7.5 \mathrm{~K}$ peaks noted in Figures 3 and 4 were reconstituted in assay buffer (as described previously in "Methods") and analyzed for their ability to bind specifically to crude membrane preparations bearing IGF receptors. Representative binding studies from stomach wall extracts from rats fed ${ }^{125}$ I-IGF-I or -II are shown in Fig. 7A and $B$. Binding of radioactivity from the $7.5 \mathrm{~K}$ peak recovered from IGF-I fed animals was identical to that of ${ }^{125}$ I-IGF-I (Fig. 7A) using human placental membranes. In addition, an excess of unlabeled IGF-I inhibited binding by $50 \%$ of both homogenate radioactivity and ${ }^{125} \mathrm{I}-$ IGF-I. Similar findings were observed for extracts in the IGF-II experiments using rat liver membrane receptor in the presence or absence of unlabeled IGF-II (Fig. 7B). Similar results were obtained using peaks obtained from stomach and intestinal luminal contents for IGF-I and -II experiments (not shown).
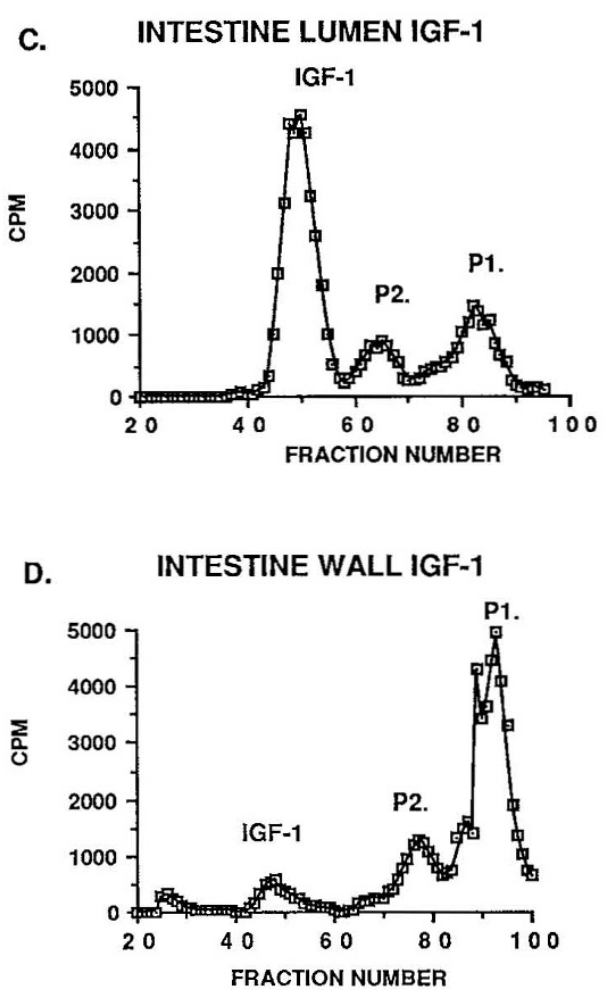

Figure 3. $A-D$, Representative of four to five chromatographs (Sephadex G-50, $0.1 \mathrm{M}$ acetic acid) of extracts of ${ }^{125} \mathrm{I}-\mathrm{IGF}-\mathrm{I}$ fed rats. $A$, Stomach lumen; $B$, stomach wall; $C$, intestinal lumen; $D$, intestinal wall. Peaks $\mathrm{P}_{1}$ and $\mathrm{P}_{2}$ represent ${ }^{125} \mathrm{I}$ and ${ }^{125} \mathrm{I}$-IGF fragments, respectively. 
A.

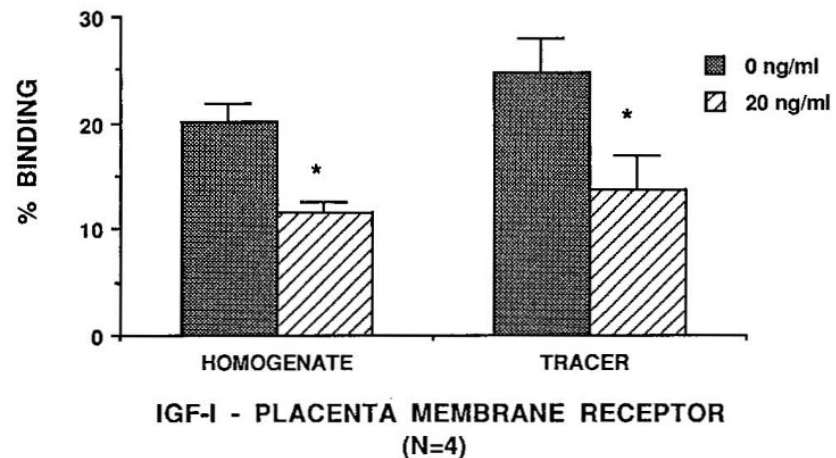

B.

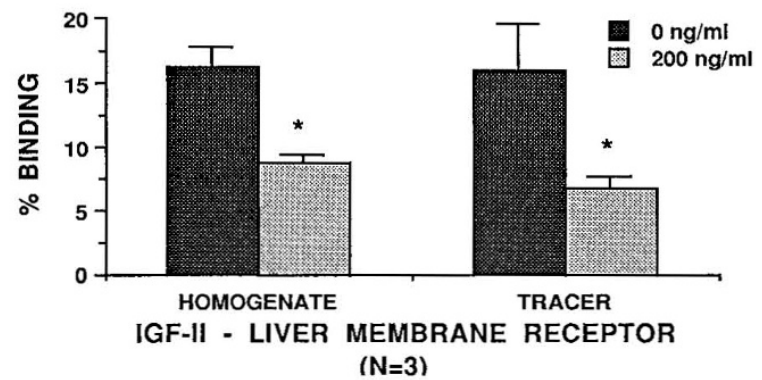

Figure 7. Specific binding of radioactivity from stomach wall homogenates (7.5 K peak) from ${ }^{125}$ I-IGF-I $(A)$ or -II $(B)$ fed animals contrasted with binding of native ${ }^{125}$ I-IGF-I or -II (tracer) with or without excess of unlabeled IGF-I $(20 \mathrm{ng} / \mathrm{mL})$ or $-\mathrm{II}(200 \mathrm{ng} / \mathrm{mL})$. Asterisk denotes significant effect of the excess of cold IGF-I or -II.

high-affinity binding sites for IGF (28) and some differential binding between IGF-I and -II exists. Binding of IGF-II to IGF-binding proteins in rat milk is roughly twice as great as that of IGF-I (15). The presence of IGFBPs may also affect the kinetics of absorption and/or degradation of IGFs in the neonatal gut. However, in the doses administered in our present experiments, more than $75 \%$ of IGF administered was not bound to carrier proteins in the ingested milk-IGF mixtures.

Absorption of biologically active IGFs to organs distant to the gut could not be documented, and whether or not absorption and transport had already occurred before the conclusion of the experiments is unknown. However, the finding of large molecular weight fragments of IGF-I in neonatal rat skin is intriguing and warrants future studies, particularly in view of a previous finding of enhanced skin epithelial maturation in rat pups injected with a similar recombinant IGF-I preparation (29).

In summary, radiolabeled IGF-I and -II were delivered orogastrically with milk to the newborn rat. Both IGF-I and -II were recovered in potentially biologically active forms $30 \mathrm{~min}$ postingestion in the gastrointestinal luminal contents and tissues, but not from organs distant to the gut. We speculate that milk-derived IGF may serve a regulatory function to stimulate stomach and intestinal growth and differentiation in the newborn.

Acknowledgments. The authors wish to thank Carole Meyer for her expert secretarial assistance and Vicki Sara, Ph.D., for advice in preparing the manuscript.

\section{REFERENCES}

1. D'Ercole AJ 1987 Somatomedins/insulin-like growth factors and fetal growth. J Dev Physiol 9:481-495

2. Han VKM, D'Ercole J, Lund PK 1987 Cellular localization of somatomedin (insulinlike growth factor) messenger RNA in the human fetus. Science 236:193-197

3. Sara VR, Hall K 1990 Insulin-like growth factors and their binding proteins. Physiol Rev 70:591-614

4. Baker J, Liu JP, Robertson EJ, Efstratiadis A 1993 Role of insulin-like growth factors in embryonic and postnatal growth. Cell 75:73-82

5. Behringer RR, Lewin TM, Quaife CJ, Paimiter RD, Brinster RL, D'Ercole AJ 1990 Expression of insulin-like growth factor I stimulates normal somatic growth in growth hormone-deficient transgenic mice. Endocrinology 127:1033-1040

6. Donovan SM, Hintz RL, Rosenfeld RG 1991 Insulin-like growth factors I and II and their binding proteins in human milk: effect of heat treatment on IGF and IGF-binding protein stability. J Pediatr Gastroenterol Nutr 13:242-253

7. Groenewegen PP, McBride BWS, Burton JH, Elsasser TH 1990 Bioactivity of milk from bST-treated cows. J Nutr 120:514-520

8. Walton PE, Etherton TD 1989 Effects of porcine growth hormone and insulin-like growth factor-I (IGF-I) on immunoreactive IGF-binding protein concentration in pigs. J Endocrinol 120:153-160

9. Schober DA, Simmen FA, Hadsell DL, Baumrucker CR 1990 Perinatal expression of type I IGF receptors in porcine small intestine. Endocrinology 126:1125-1132

10. Werner H, Woloschak M, Adamo M, Shen-Orr Z, Roberts Jr CT, LeRoith D 1989 Developmental regulation of the rat insulin-like growth factor I receptor gene. Proc Natl Acad Sci USA 86:7451-7455

11. Thornburg W, Rao RK, Matrisian LM, Magun BE, Koldovsky, O 1987 Effect of maturation on gastrointestinal absorption of epidermal growth factor in rats. Am J Physiol 253:G68-G71

12. Britton JR, Koldovsky, O 1989 The development of luminal protein digestion: implications for dietary polypeptides. J Pediatr Gastroenterol Nutr 9:144-161

13. Rechler MM, Podskalny JM, Nissley S 1977 Characterization of the binding of multiplication-stimulating activity to a receptor for growth polypeptides in chick embryo fibroblasts. J Biol Chem 252:3898-3910

14. Hall K, Takano K, Fryklund L 1974 Radioreceptor assay for somatomedin A. J Clin Endocrinol Metab 39:973-976

15. Philipps AF, Wilson JM, Rao RK, McCracken DM, Koldovsky, O 1991 Presence of insulin-like growth factors and their binding proteins in rat milk. In: Raizada MK, LeRoith D (eds) Molecular Biology and Physiology of Insulin and Insulin-like Growth Factors. Plenum Press, New York, pp 179-186

16. Davis TP, Culling-Berglund AJ 1985 High performance liquid chromatographic analysis of in vitro central neuropeptide processing. J Chromatogr B Biomed Appl 327:279-292

17. Marshall RN, Underwood LE, Voina SJ, Foushee DB, Van Wyk JJ 1974 Characterization of the insulin and somatomedin-C receptors in human placental cell membranes. J Clin Endocrinol Metab 39:283-292

18. Philipps A, Drakenberg K, Persson B, Sjogren B, Eklof AC, Hall K, Sara V 1989 The effects of altered nutritional status upon insulin-like growth factors and their binding proteins in neonatal rats. Pediatr Res 26:128-134

19. Corps AN, Brown KD 1987 Stimulation of intestinal epithelial cell proliferation in culture by growth factors in human and ruminant mammary secretions. J Endocrino 113:285-290

20. Ichiba H, Kusuda S, Itagane Y, Fujita K, Issiki G 1992 Measurement of growth promoting activity in human milk using a fetal small intestinal cell line. Biol Neonate $61: 47-53$

21. Hill DJ, Han VKM 1991 Paracrinology of growth regulation. J Dev Physiol 15:92104

22. Lund PK, Ulshen MH, Rountree DB, Selub SE, Buchan AM 1990 Molecular biology of gastrointestinal peptides and growth factors: relevance to intestinal adaptation. Digestion 46:66-73

23. Young GP, Taranto TM, Jonas HA, Cox AJ, Hogg A, Werther GA 1990 Insulin-like growth factors and the developing and mature rat small intestine: receptors and biological actions. Digestion 46:240-252

24. Hodgkinson SC, Moore L, Napier JR, Davis SR, Bass JJ, Gluckman PD 1989 Characterization of insulin-like growth factor binding proteins in ovine tissue fluids. J Endocrinol 120:429-438

25. Donovan SM, Hintz RL, Wilson DM, Rosenfeld RG 1991 Insulin-like growth factors $\mathrm{I}$ and II and their binding proteins in rat milk. Pediatr Res 29:50-55

26. Rao RK, Lam K, Philipps AF, Williams C, Lake M, Koldovsky, O 1993 Presence of multiple forms of peptidase inhibitors in rat milk. J Pediatr Gastroenterol Nutr 17:414-420

27. Blum WF, Ranke MB 1990 Insulin-like growth factor binding proteins (IGFBPs) with special reference to IGFBP-3. Acta Paediatr Scand Suppl 367:55-62

28. Clemmons DR 1991 Insulin-like growth factor binding proteins: roles in regulating IGF physiology. J Dev Physiol 15:105-110

29. Philipps AF, Persson B, Hall K, Lake M, Skottner A, Sanengen T, Sara VR 1988 The effects of biosynthetic insulin-like growth factor-I supplementation on somatic growth, maturation, and erythropoiesis on the neonatal rat. Pediatr Res 23:298-305 